\title{
Sustainable effective use of brackish and canal water for rice-wheat crop production and soil health
}

\author{
Khalil AHMED ${ }^{1,2}$, Amar Iqbal SAQIB ${ }^{1}$, Ghulam QADIR ${ }^{1}$, Muhammad Qaisar NAWAZ ${ }^{1}$, \\ Muhammad RIZWAN ${ }^{1}$, Syed Saqlain HUSSAIN ${ }^{1}$, Muhammad IRFAN ${ }^{1}$, Muhammad \\ Mohsin $\mathrm{ALI}^{3}$
}

Received September 20, 2020; accepted June 22, 2021. Delo je prispelo 20. Septembra 2020, sprejeto 22. junija 2021

\begin{abstract}
Sustainable effective use of brackish and canal water for ricewheat crop production and soil health

Abstract: A pot study was conducted to develop reasonable irrigation scheduling methods for rice-wheat crop rotation by conjunctive use of low-quality brackish water and good quality canal water. Treatments tested were; $\mathrm{T}_{1}$ (canal water), $\mathrm{T}_{2}$ (brackish water), $\mathrm{T}_{3}$ (brackish water for rice and canal water for wheat), $\mathrm{T}_{4}$ (last two irrigations to rice, and initial two irrigations to wheat with canal water), $\mathrm{T}_{5}$ (last two irrigations to rice but two initial and one last irrigation to wheat with canal water). Results revealed that irrigation with canal water resulted in the maximum mean biomass and grain yield of rice and wheat crops followed by cyclic use of brackish and canal water. While continuous irrigation with brackish water resulted the lowest mean biomass and grain yield. The different modes of irrigations also influenced chemical properties of soil, brackish water adversely affected the soil properties, and maximum $\mathrm{pH}$ of soil saturated paste $\left(\mathrm{pH}_{\mathrm{s}}\right)$, electrical conductivity of soil extract (EC $\mathrm{E}_{\mathrm{e}}$ ) and sodium adsorption ratio (SAR) were recorded where brackish water was used continuously. Therefore, it was concluded that when water is valuable and freshwater resources are limited, cyclic use of the canal and brackish water is also profitable with marginal effect on biomass and grain yield and proves least detrimental for soil health.
\end{abstract}

Key words: canal water; brackish water; rice; wheat; soil health
Trajnostna in učinkovita raba brakične in vodovodne vode za pridelavo riža in pšenice in ohranjanje zdravja tal

Izvleček: Izveden je bil lončni poskus za razvoj načrta smiselnega namakanja v kolobarju riža in pšenice s hkratno uporabo brakične vode slabe kakovosti in kakovostno vodo iz vodovoda. Obravnavanja so obsegala: $\mathrm{T}_{1}$ (voda iz vodovoda), $\mathrm{T}_{2}$ (brakična voda), $\mathrm{T}_{3}$ (brakična voda za riž in voda iz vodovoda za pšenico), $\mathrm{T}_{4}$ (dve zadnji namakanji riža in začetno namakanjem pšenice $z$ vodo iz vodovoda), $T_{5}$ (dve zadnji namakanji riža, dve začetni in zadnje namakanje pšenice $\mathrm{z}$ vodo iz vodovoda). Rezultati so pokazali, da je namakanje $z$ vodo iz vodovoda dalo največjo poprečno biomaso in največji pridelek zrnja riža in enake rezultate pri pšenici pri izmenični rabi brakične in vodovodne vode. Stalno namakanje $\mathrm{z}$ brakično vodo je dalo najmanjšo poprečno biomaso in najmanjši pridelek zrnja. Različni načini namakanja so vplivali tudi na kemijske lastnosti tal. Brakična voda je nanje vplivala negativno. Pri njeni stalni uporabi je bil zabeležen najvišji $\mathrm{pH}$ tal $\left(\mathrm{pH}_{\mathrm{s}}\right)$, največja električna prevodnost izvlečka tal $\left(\mathrm{EC}_{\mathrm{e}}\right)$ in največja adsorpcija natrija (SAR). Na osnovi tega lahko zaključimo, da je tam, kjer so viri sladke vode omejeni, izmenična uporaba brakične in vodovodne vode donosna saj ima majhen učinek na biomaso in pridelek zrnja in se izkaže manj škodljiva za zdravje tal.

Ključne besede: vodovodna voda; brakična voda; riž; pšenica; zdravje tal

1 Soil Salinity Research Institute (SSRI), Pindi Bhattian, Pakistan

2 Corresponding author, e-mail: khalilahmeduaf@gmail.com

3 Pakistan Agricultural Research Council, Islamabad 


\section{INTRODUCTION}

Due to Pakistan's arid and semi-arid climate, the agriculture sector of the country is heavily dependent on irrigated farming. However, a considerable gap exists between increasing demand and water supply and farmers are forced to pump the groundwater, which is about $70-80 \%$ brackish (Latif and Beg 2004). Drought prevailing conditions and decreased the surface water supply may intensify the practice of irrigation with brackish water that may results in problem of salinity in irrigated lands (Qadir et al., 2007). Hence, farmers' poor knowledge to manage the brackish water for irrigation is one of the major reasons for the land deterioration.

Soil sodicity is generally described as presence of relative amounts of sodium in the soil solution or on the cation exchange sites. Sodium adsorption ratio (SAR) represents the soluble $\mathrm{Na}^{+}$concentration relative to the soluble divalent cation concentrations in the soil solution (Qadir et al., 2008). Soils with SAR more than 13 are dispersive and suffer from serious physical problems e.g. permeability to water and air is restricted (Biswas et al., 2014). Further, water with high sodium content results in dispersion of clay particles and clogging of soil pores (Levy et al., 2003); Na-saturation of clay complex (Minhas et al., 2019); impedes aeration and loss in soil permeability (Choudhary et al., 2011); thereby negatively impacting crop productivity through toxicity of $\mathrm{Na}^{+}$, nutritional imbalances and adverse osmotic effect (Sharma et al., 2016; Murtaza et al., 2017).

Several researchers decided to designate the strategies for optimal use of different quality waters to attain secure and predictable yields on a long-term sustainable basis. Nevertheless, safe and successful use of poor-quality water will require careful planning, stringent monitoring procedures, and efficient management practices to avoid further land degradation (FAO, 2011). Two different strategies can be employed to use the fresh water and poor-quality groundwater, i.e., I) a cyclic mode, in which subsurface poor-quality water and canal water are used separately, and II) a blending model, in which good and poor-quality water are used simultaneously (Qureshi et al., 2004).

The cyclic mode involves brackish and good quality water in different crop rotations comprising salt-tolerant and salt-sensitive crops. In general, canal water or good quality water is used before planting and at early growth stages, while brackish water is used after seedling establishment (Latteef, 2010). In Pakistan, the ricewheat cropping pattern covers $2.3 \times 10^{-6}$ ha (Qureshi and Barrett-Lennard, 1998). Rice is relatively tolerant to sodicity, while wheat is tolerant to salinity (Qadir et al. 2001). It is a very well-established fact that germi- nation and seedling stages are categorized as the most sensitive growth stages in most crops. Subsequently, irrigation with good quality water has been advocated at early growth stages and then switching over to brackish water at later growth stages when the plant can tolerate high salt stress (Minhas and Gupta, 1993). Efforts have been made to counteract brackish water's detrimental effects through blended and cyclic approaches (Rhoades, 1998). Furthermore, conjunctive use of brackish water with surface water can generate double agricultural revenues, and that profits may be more during drought periods (Bredehoeft and Young, 1983).

In a pot experiment, Gandahi et al. (2017) studied the response of different cotton varieties against conjunctive use of non-saline and saline water. They concluded that cotton genotypes performed better when six irrigations were provided with fresh water and six irrigations with salty water in a conjunctive manner. Similarly, in a field experiment, Chen et al. (2018) observed that shoot dry mass and cotton yield decreased significantly when irrigated with brackish water than freshwater. They stated that an optimal mix of alternating non-saline and saline water may be an effective strategy for cotton production and avoiding secondary salinization when using saline water. Minhas et al. (2007) evaluated the effect of fresh water and alkali water on rice-wheat crop rotation. The yield of rice and wheat crops, was affected negatively when irrigated with alkali water; however, rice was more sensitive to alkali water irrigation. They concluded that cyclic use of alkali and good quality water could be a preferable irrigation mode to avoid the build up of salts in soils.

In a field experiment, Murad et al. (2018) applied the fresh water and brackish water at different maize crop growth stages. They stated that freshwater application yielded the highest grain and straw yield of maize. They concluded that freshwater irrigation at an early sensitive stage while conjunctive use of saline water with fresh water at later growth stages may minimize the yield losses. Therefore, the present research work was carried out to develop reasonable irrigation scheduling methods for rice-wheat crop rotation by conjunctive use of the low-quality brackish water and limited freshwater resources.

\section{MATERIALS AND METHODS}

\subsection{EXPERIMENTAL SETUP}

A pot study was conducted in the wirehouse of Soil Salinity Research Institute Pindi Bhattian, Hafizabad. A normal soil $\left\{\mathrm{pH}_{\mathrm{s}}=7.98, \mathrm{EC}_{\mathrm{e}}=2.22\left(\mathrm{dS} \mathrm{m} \mathrm{m}^{-1}\right)\right.$, 
$\mathrm{SAR}=36.50$ and texture $=$ sandy clay loam $\}$ was filled in glazed pots at the rate of $16 \mathrm{~kg} /$ pot. Pots were arranged in Completely Randomized Design (CRD) with three replications to give a total of 15 pots. During the experiment, the average weather conditions were: $13.2 \pm$ $2.8^{\circ} \mathrm{C}$ minimum temperature, $41.4 \pm 3.8^{\circ} \mathrm{C}$ maximum temperature, $35.6 \pm 3.4 \%$ minimum relative humidity, $72.6 \pm 4.6 \%$ maximum relative humidity, maximum sunshine hours, $14 \mathrm{~h}$ and $8 \mathrm{~min}$ and minimum sunshine hours, $7 \mathrm{~h}$ and $36 \mathrm{~min}$.

\subsection{TREATMENTS DETAILS AND CROP ROTA- TION}

Treatments tested were comprised of $\mathrm{T}_{1}$ (canal water), $\mathrm{T}_{2}$ (consistence use of brackish water), $\mathrm{T}_{3}$ (brackish water for rice and canal water for wheat, seasonal cyclic use), $\mathrm{T}_{4}$ (last two irrigations to rice, and initial two irrigations to wheat with canal water, supplementation of canal water at sensitive stages), $\mathrm{T}_{5}$ (last two irrigations to rice but two initial and one last irrigation to wheat with canal water). Rice-wheat crop rotation was used for three years (2013 to 2016). Thirty days old seedlings of rice ('Shaheen Basmati') were transplanted in the $2^{\text {nd }}$ week of July 2013, 2014, 2015 at the rate of three seedlings per pot. Fertilizers dose viz. 110-90-60 NPK kg $\mathrm{ha}^{-1}$ was used for rice crop. Half of the recommended nitrogen (urea) and full dose of P (single super phosphate) and $\mathrm{K}$ (sulphate of potash) were applied at transplanting while the remaining half dose of nitrogen was applied thirty days after transplanting. The pots were irrigated as per crop requirement and approximately 2 liters pot $^{-1}$ irrigation $^{-1}$ were given, a total of 20 irrigations were applied in each season for rice crop. All the plant protection and agronomical practices were carried out uniformly. Rice crop was harvested in the $2^{\text {nd }}$ week of November, and data about biomass and grain yield was documented. After the harvest of rice crop, in the same layout, fertilizers dose viz. 120-110-70 NPK $\mathrm{kg} \mathrm{ha}^{-1}$ was applied. Half of the recommended nitrogen (urea) and full dose of P (single super phosphate) and $\mathrm{K}$ (sulphate of potash) were applied at sowing while the remaining half dose of nitrogen was applied thirty days after sowing. Ten seeds of wheat ('Inqlab-91') were sown in each pot in the $3^{\text {rd }}$ week of November 2013, 2014 and 2015. Thirty days after the germination, plants were thinned, and three seedlings/pot were maintained. The pots were irrigated as per crop requirement and approximately 2 liters pot $^{-1}$ irrigation $^{-1}$ were given, a total of 6 irrigations were applied in each season for wheat crop. The crop was raised to maturity and harvested in the $2^{\text {nd }}$ week of April, and data about biomass and grain yield were recorded.

\subsection{SOIL AND WATER ANALYSIS}

Before the start of study and after the harvest of $3^{\text {rd }}$ wheat crop soil samples were air dried, passed through $2 \mathrm{~mm}$ sieve and analyzed for $\mathrm{pH}_{\mathrm{s}}, \mathrm{EC}_{\mathrm{e}}$ and SAR (U.S. Salinity Laboratory Staff, 1954). Soil pH of the saturated paste was measured by using $\mathrm{pH}$ meter (Microcomputer pH-vision cole parmer model 05669-20). Electrical conductivity of the irrigation water and soil saturated paste extract was measured with the help of conductivity meter (WTW conduktometer LF 191). The $\mathrm{Na}^{+}$ contents were determined by flame photometer (digiflame code DV 710) while $\mathrm{Ca}^{2+}$ and $\mathrm{Mg}^{2+}$ were determined titrimetrically. Sodium adsorption ratio (SAR) was calculated as follows where ionic concentration of the saturation extracts is given in $\mathrm{mmol}_{\mathrm{e}} \mathrm{l}^{-1}$. SAR $=\mathrm{Na}^{+}$ $/\left[\left(\mathrm{Ca}^{2+}+\mathrm{Mg}^{2+}\right) / 2\right]^{1 / 2}$. Soil texture was determined by hydrometer method (Bedaiwy, 2012). Carbonate contents $\left(\mathrm{CO}_{3}{ }^{2-}\right.$ and $\left.\mathrm{HCO}_{3}^{-}\right)$was determined via titration with standard $\mathrm{H}_{2} \mathrm{SO}_{4}$. Residual sodium carbonate (RSC) was calculated by (Eaton, 1950) as follows:

$$
\mathrm{RSC}=\left(\mathrm{CO}_{3}{ }^{2-} \text { and } \mathrm{HCO}_{3}^{-}\right)-\left[\left(\mathrm{Ca}^{2+}+\mathrm{Mg}^{2+}\right)\right.
$$

\subsection{STATISTICAL ANALYSES}

The collected crop data were subjected to analysis of variance. The treatment means comparison was made using the Least Significant Difference Test at $5 \%$ probability level (Steel et al., 1997) using STATISTIX 8.1 package software.

Table 1: Analysis of irrigation waters used in study

\begin{tabular}{llll}
\hline Parameters & Units & Brackish water & Canal water \\
\hline Electrical conductivity of irrigation water $\left(\mathrm{EC}_{\mathrm{iw}}\right)$ & $(\mathrm{dS} \mathrm{m})^{-1}$ & 3.29 & 0.32 \\
Sodium adsorption ratio (SAR) & $\left(\mathrm{mmol}_{\mathrm{e}} \mathrm{l}^{-1}\right)^{1 / 2}$ & 25.52 & 0.53 \\
Residual sodium carbonate (RSC) & $\left(\mathrm{me} \mathrm{l}^{-1}\right)$ & 2.54 & $\mathrm{Nil}$ \\
\hline
\end{tabular}




\section{RESULTS}

\subsection{RICE CROP}

Data in Table 2 showed that different irrigation modes had a significant effect $(p<0.05)$ on rice biomass yield. Irrigation with canal water produced the maximum biomass yield during all three seasons, while continuous irrigation with brackish water negatively affected rice crop biomass yield. Based on the mean value of three seasons, irrigation with canal water $\left(\mathrm{T}_{1}\right)$ produced the maximum biomass yield of $254.53 \mathrm{~g} / \mathrm{pot}$ followed by $\left(\mathrm{T}_{3}\right)(214.54 \mathrm{~g} / \mathrm{pot})$, where canal water and brackish water was used in a cyclic mode. Whereas continuous irrigation with brackish water produced the minimum biomass yield of $180.63 \mathrm{~g} /$ pot. A similar trend was also observed in the case of grain yield, based on average data of three seasons, maximum grain yield $(55.40 \mathrm{~g} / \mathrm{pot})$ was documented where canal water was used for irrigation followed by cyclic mode of irrigation (brackish water for rice and canal water for wheat) which yielded the grain yield of $42.81 \mathrm{~g} /$ pot (Table 3 ). However, it was statistically $(p<0.05)$ similar to all the other treatments. Continuous irrigation with brackish water negatively impacted grain yield, and the lowest mean grain yield $(36.64 \mathrm{~g} / \mathrm{pot})$ was divulged with this mode of irrigation.

\subsection{WHEAT CROP}

Growth characteristics like biomass and grain yield of the wheat crop were also significantly influenced by different irrigation modes. Data presented in Table 4 showed that the highest mean value for biomass yield (84.35 g/pot) was documented in $\mathrm{T}_{1}$ (canal water irrigation) followed by $\mathrm{T}_{3}$ with biomass yield of $(78.55 \mathrm{~g} /$ pot), and both the treatments were significant $(p<0.05)$ from each other. On average, the minimum biomass yield of $69.02 \mathrm{~g} /$ pot was recorded in $\mathrm{T}_{2}$, indicating that continuous irrigation with brackish water significantly reduced the biomass yield. Grain yield also responded significantly to different treatments of irrigation during all three seasons. Data in Table 5 illustrated that the maximum grain yield $(35.92 \mathrm{~g} / \mathrm{pot})$ was observed with canal irrigation followed by cyclic mode of irrigation $(32.09 \mathrm{~g} / \mathrm{pot})$. On the other hand, the lowest grain yield (27.25) was observed in $\mathrm{T}_{2}$, a treatment where brackish irrigation water was used continuously to irrigate the pots.

\subsection{SOIL PROPERTIES}

Chemical properties of surface soil were also influenced by the different modes of irrigations and $\mathrm{pH}_{\mathrm{s}}$, $\mathrm{EC}_{\mathrm{e}}$ and SAR gradually increased during the three years of experimentation. Soil $\mathrm{pH}_{\mathrm{s}}$ steadily increased by continuous irrigation with brackish water as compared to other modes of irrigation. At the end of the study maximum increase of $11.52 \%$ over its initial value in soil, $\mathrm{pH}_{\mathrm{s}}$ was recorded with brackish water irrigation (Table 6). On the contrary, a minimum increase in soil $\mathrm{pH}_{\mathrm{s}}$ $(1.12 \%)$ was recorded in canal water irrigation, while in the cyclic mode of irrigation, this increase was (4.38 $\%)$ over its initial value. A similar tendency was observed in soil $\mathrm{EC}_{\mathrm{e}}$; different modes of irrigation resulted in the buildup of salts in the soil; however, accumulation of salts was more with brackish water. At the end of the study, a maximum increase in $\mathrm{EC}_{\mathrm{e}}(234.23 \%)$ was observed in $\mathrm{T}_{2}$ (brackish water), whereas, minimum increase $(5.85 \%)$ was observed in $\mathrm{T}_{1}$ (canal water) (Table 7). Soil sodicity was also increased remarkably by various modes of irrigation. Maximum sodicity was developed where brackish water was used continuously for three years, and an increase of $648.90 \%$ in SAR over its

Table 2: Effect of conjunctive use of brackish and canal water on rice biomass yield (g/pot)

\begin{tabular}{|c|c|c|c|c|}
\hline Treatments & $1^{\text {st }} \mathrm{crop}$ & $2^{\text {nd }}$ crop & $3^{\text {rd }}$ crop & Mean \\
\hline $\mathrm{T}_{1}$ Canal water & $256.98 \mathrm{~A}$ & $263.38 \mathrm{~A}$ & $243.22 \mathrm{~A}$ & $254.53 \mathrm{~A}$ \\
\hline $\mathrm{T}_{2}$ Consistence use of brackish water & $236.14 \mathrm{~B}$ & $164.80 \mathrm{~A}$ & $140.96 \mathrm{D}$ & $180.63 \mathrm{C}$ \\
\hline $\begin{array}{l}\mathrm{T}_{3} \text { Brackish water for rice and canal water for wheat seasonal } \\
\text { cyclic use }\end{array}$ & $234.88 \mathrm{~B}$ & $216.55 \mathrm{~B}$ & $192.20 \mathrm{~B}$ & $214.54 \mathrm{~B}$ \\
\hline $\begin{array}{l}\mathrm{T}_{4} \text { Last two irrigations to rice and initial two irrigations to } \\
\text { wheat with canal water (supplementation of canal water at } \\
\text { sensitive stages) }\end{array}$ & $240.13 \mathrm{~B}$ & $190.11 \mathrm{C}$ & $162.78 \mathrm{C}$ & 197.67 BC \\
\hline $\begin{array}{l}T_{5} \text { Last two irrigations to rice but two initial and one last } \\
\text { irrigation to wheat with canal water }\end{array}$ & $237.86 \mathrm{~B}$ & 194.36 & $170.28 \mathrm{C}$ & $200.83 \mathrm{BC}$ \\
\hline
\end{tabular}

Different letters in the same column indicate significant differences by LSD at $p \leq 0.05$ 
Table 3: Effect of conjunctive use of brackish and canal water on rice grain yield (g/pot)

\begin{tabular}{|c|c|c|c|c|}
\hline Treatments & $1^{\text {st }}$ crop & $2^{\text {nd }}$ crop & $3^{\text {rd }}$ crop & Mean \\
\hline $\mathrm{T}_{1}$ Canal water & $55.23 \mathrm{~A}$ & $57.48 \mathrm{~A}$ & $53.50 \mathrm{~A}$ & $55.40 \mathrm{~A}$ \\
\hline $\mathrm{T}_{2}$ Consistence use of brackish water & $48.13 \mathrm{~B}$ & $32.18 \mathrm{D}$ & $29.62 \mathrm{D}$ & $36.64 \mathrm{~B}$ \\
\hline $\begin{array}{l}\mathrm{T}_{3} \text { Brackish water for rice and canal water for wheat seasonal } \\
\text { cyclic use }\end{array}$ & $46.64 \mathrm{~B}$ & $41.91 \mathrm{~B}$ & $39.88 \mathrm{~B}$ & $42.81 \mathrm{~B}$ \\
\hline $\begin{array}{l}\mathrm{T}_{4} \text { Last two irrigations to rice and initial two irrigations to } \\
\text { wheat with canal water (supplementation of canal water at } \\
\text { sensitive stages) }\end{array}$ & $47.89 \mathrm{~B}$ & $36.04 \mathrm{C}$ & $33.41 \mathrm{C}$ & $39.11 \mathrm{~B}$ \\
\hline $\begin{array}{l}\mathrm{T}_{5} \text { Last two irrigations to rice but two initial and one last } \\
\text { irrigation to wheat with canal water }\end{array}$ & $50.09 \mathrm{~B}$ & $36.76 \mathrm{C}$ & $32.98 \mathrm{C}$ & $39.94 \mathrm{~B}$ \\
\hline
\end{tabular}

Different letters in the same column indicate significant differences by LSD at $p \leq 0.05$

initial value was observed (Table 8). In contrast, a minimum increase $(27.39 \%)$ in SAR over its initial value was recorded, canal water was used for irrigation.

\section{DISCUSSION}

Due to Pakistan's arid to semi-arid climate, about 70-75\% of the country's tube wells withdraw the brackish groundwater (Ghafoor et al., 1991). Furthermore, many areas of the country with freshwater resources are endangered with contamination due to this excessive withdrawal of brackish groundwater. Under most situations, subsurface brackish water and canal water can be applied in different modes of irrigations (cyclic, blending) to meet the crop water demands. Allocation of these two different quality waters can be done depending upon season, type of crop, and crop growth stage so that salt stress is minimized. For this purpose, we designed an irrigation schedule for rice wheat-crop rotation, where both waters were used in seasonal cyclic mode, and canal (non-saline) water was used at the salt-sensitive stage of crop growth, switching over to brackish water at the tolerant stage. Results of the study showed that $\mathrm{pH}_{\mathrm{s}}, \mathrm{EC}_{\mathrm{e}}$ and $\mathrm{SAR}$ of soil increased gradually during three years; however, the rate of increase was more where brackish water alone with $\left\{\mathrm{EC}_{\mathrm{iw}}=3.29\right.$ $\left(\mathrm{dS} \mathrm{m}{ }^{-1}\right), \mathrm{SAR}=25.52$, and $\left.\mathrm{RSC}=2.54\left(\mathrm{me} \mathrm{l}^{-1}\right)\right\}$ was used continuously for three years. This high $\mathrm{pH}_{\mathrm{s}}, \mathrm{EC}_{\mathrm{e}}$, and SAR due to brackish water may be explained that salt solution concentrated when water loss through evapotranspiration and induces the salinity/sodicity (Minhas et al., 2007). Different researchers reported similar findings that irrigation with brackish water resulted the residual in salinity and sodicity build up in soils (Avais et al., 2018; Zaka et al., 2018; Qadir et al., 2019). Continuous irrigation with brackish water having SAR 10.4 $\left(\mathrm{mmol} \mathrm{l}^{-1}\right)^{1 / 2}$ may reduced rice and wheat productivity by 16 and $14 \%$, respectively and resulted in buildup of exchangeable sodium (Sheoran et al., 2021). Similarly in a pot study, Hussain et al. (2016) reported that saline irrigation ( $5.7 \mathrm{dS} \mathrm{m}^{-1}$ ) impaired growth of wheat plants and adversely affected the grain and dry matter yield. Therefore, it emerges that high water demanding rotations like rice-wheat are even more prone to sodicity problem when irrigated with sodic waters (Minhas et

Table 4: Effect of conjunctive use of brackish and canal water on wheat biomass yield (g/pot)

\begin{tabular}{|c|c|c|c|c|}
\hline Treatments & $1^{\text {st }}$ crop & $2^{\text {nd }}$ crop & $3^{\text {rd }}$ crop & Mean \\
\hline $\mathrm{T}_{1}$ Canal water & $90.31 \mathrm{~A}$ & $78.40 \mathrm{~A}$ & $84.36 \mathrm{~A}$ & $84.35 \mathrm{~A}$ \\
\hline $\mathrm{T}_{2}$ Consistence use of brackish water & $73.22 \mathrm{C}$ & $67.92 \mathrm{D}$ & $65.94 \mathrm{D}$ & $69.02 \mathrm{D}$ \\
\hline $\begin{array}{l}T_{3} \text { Brackish water for rice and canal water for wheat seasonal } \\
\text { cyclic use }\end{array}$ & $84.86 \mathrm{AB}$ & $74.18 \mathrm{~B}$ & $76.62 \mathrm{~B}$ & $78.55 \mathrm{~B}$ \\
\hline $\begin{array}{l}\mathrm{T}_{4} \text { Last two irrigations to rice and initial two irrigations to } \\
\text { wheat with canal water (supplementation of canal water at } \\
\text { sensitive stages) }\end{array}$ & $80.17 \mathrm{BC}$ & $71.41 \mathrm{C}$ & $72.78 \mathrm{C}$ & $74.78 \mathrm{C}$ \\
\hline $\begin{array}{l}\mathrm{T}_{5} \text { Last two irrigations to rice but two initial and one last } \\
\text { irrigation to wheat with canal water }\end{array}$ & $81.60 \mathrm{AB}$ & $71.98 \mathrm{BC}$ & $73.24 \mathrm{C}$ & $75.60 \mathrm{BC}$ \\
\hline
\end{tabular}

Different letters in the same column indicate significant differences by LSD at $p \leq 0.05$ 
Table 5: Effect of conjunctive use of brackish and canal water on wheat grain yield (g/pot)

\begin{tabular}{|c|c|c|c|c|}
\hline Treatments & $1^{\text {st }}$ crop & $2^{\text {nd }}$ crop & $3^{\text {rd }}$ crop & Mean \\
\hline $\mathrm{T}_{1}$ Canal water & $38.63 \mathrm{~A}$ & $32.96 \mathrm{~A}$ & $36.18 \mathrm{~A}$ & $35.92 \mathrm{~A}$ \\
\hline $\mathrm{T}_{2}$ Consistence use of brackish water & $30.76 \mathrm{C}$ & $26.47 \mathrm{D}$ & $24.52 \mathrm{D}$ & $27.25 \mathrm{D}$ \\
\hline $\begin{array}{l}T_{3} \text { Brackish water for rice and canal water for wheat seasonal } \\
\text { cyclic use }\end{array}$ & $35.77 \mathrm{AB}$ & $29.65 \mathrm{~B}$ & $30.86 \mathrm{~B}$ & $32.09 \mathrm{~B}$ \\
\hline $\begin{array}{l}T_{4} \text { Last two irrigations to rice and initial two irrigations to } \\
\text { wheat with canal water (supplementation of canal water at } \\
\text { sensitive stages) }\end{array}$ & $33.80 \mathrm{BC}$ & $27.65 \mathrm{CD}$ & $27.92 \mathrm{C}$ & $29.79 \mathrm{C}$ \\
\hline $\begin{array}{l}\mathrm{T}_{5} \text { Last two irrigations to rice but two initial and one last } \\
\text { irrigation to wheat with canal water }\end{array}$ & $34.30 \mathrm{BC}$ & $28.14 \mathrm{BC}$ & $28.56 \mathrm{C}$ & $30.33 \mathrm{BC}$ \\
\hline
\end{tabular}

Different letters in the same column indicate significant differences by LSD at $p \leq 0.05$

al., 2019). This development of sodicity and salinity was also correlated to proportions of brackish water used in different irrigation modes. At the end of the study, $\mathrm{EC}_{\mathrm{e}}$ value was 4.17 , where brackish and canal waters were used in cyclic mode $\left(\mathrm{T}_{3}\right)$ while a little variation was observed between $\mathrm{T}_{4}(6.08)$ and $\mathrm{T}_{5}$ (5.98) where canal water was supplied at the sensitive stages of crop growth. Similarly, at the end of the study, corresponding final values of SAR were 18.64 with cyclic mode $\left(\mathrm{T}_{3}\right)$ and 35.15 and 35.14 in $\left(\mathrm{T}_{4}\right)$ and $\left(\mathrm{T}_{5}\right)$, respectively, where canal water was used at salt-sensitive stages. In contrast, brackish water was used at tolerant stages of crop growth. Our results are supported by earlier findings of (Minhas et al., 2007) that cyclic use or mixing of good quality water with higher alkaline water resulted in lower exchangeable sodiu percentage (ESP) value (sodicity).

Salinity induced reduction in biomass and grain yield of rice and wheat crop was observed, and maximum reduction was documented in treatment where brackish water alone was used for irrigation, whereas, application of canal water alone or at sensitive growth stages and cyclic mode of irrigation showed less reduc- tion in these attributes. This reduced biomass and grain yield of rice and wheat with brackish water were due to sodicity/salinity in the soil as we discussed earlier that $\mathrm{pH}_{s}, \mathrm{EC}_{e}$ and SAR of soil increased gradually with brackish water. This accumulation of toxic salts in root zone asserted physiological stress and negatively affected the physical and morphological characters of plants and consequently, crop growth is reduced (De Oliveira et al., 2013; Pessarakli, 2016). Under salt stress, the plant experiences osmotic and ionic stresses, leading to leaf senescence, reduced water uptake, photosynthetic activity, transpiration rate, and promoted metabolic alterations (Munns, 2002; Amirjani, 2011).

According to Zeng and Shannon (2003), salt stress in rice crop before the heading reduces the number and mass of panicles during the three-leaf stages until booting. Further, at the flowering stage, salt stress adversely affected photosynthesis, which resulted in unfilled spikelet formation and ultimately the number of filled grains in the panicle decreased (Moradi, 2002; Zhang et al., 2015). Brackish water salinity resulted in the reduce biomass, leaf area, number of tillers, delay in flowering

Table 6: Effect of conjunctive use of brackish and canal water on soil $\mathrm{pH}_{\mathrm{s}}$

\begin{tabular}{|c|c|c|c|c|}
\hline Treatments & $1^{\text {st }}$ year & $2^{\text {nd }}$ year & $3^{\text {rd }}$ year & $\begin{array}{l}\% \text { increase over } \\
\text { initial the value }\end{array}$ \\
\hline $\mathrm{T}_{1}$ Canal water & 8.00 & 8.05 & 8.07 & 1.12 \\
\hline $\mathrm{T}_{2}$ Consistence use of brackish water & 8.41 & 8.59 & 8.90 & 11.52 \\
\hline $\begin{array}{l}T_{3} \text { Brackish water for rice and canal water for } \\
\text { wheat seasonal cyclic use }\end{array}$ & 8.17 & 8.25 & 8.33 & 4.38 \\
\hline $\begin{array}{l}\mathrm{T}_{4} \text { Last two irrigations to rice and initial two } \\
\text { irrigations to wheat with canal water } \\
\text { (supplementation of canal water at sensitive stages) }\end{array}$ & 8.35 & 8.45 & 8.65 & 8.39 \\
\hline $\begin{array}{l}\mathrm{T}_{5} \text { Last two irrigations to rice but two initial and } \\
\text { one last irrigation to wheat with canal water }\end{array}$ & 8.30 & 8.42 & 8.63 & 8.14 \\
\hline
\end{tabular}


Table 7: Effect of conjunctive use of brackish and canal water on soil EC

\begin{tabular}{|c|c|c|c|c|}
\hline Treatments & $1^{\text {st }}$ year & $2^{\text {nd }}$ year & $3^{\text {rd }}$ year & $\begin{array}{l}\% \text { increase over } \\
\text { the initial value }\end{array}$ \\
\hline $\mathrm{T}_{1}$ Canal water & 2.27 & 2.32 & 2.35 & 5.85 \\
\hline $\mathrm{T}_{2}$ Consistence use of brackish water & 3.30 & 5.08 & 7.42 & 234.23 \\
\hline $\begin{array}{l}\mathrm{T}_{3} \text { Brackish water for rice and canal water for wheat } \\
\text { seasonal cyclic use }\end{array}$ & 2.58 & 3.72 & 4.17 & 87.83 \\
\hline $\begin{array}{l}\mathrm{T}_{4} \text { Last two irrigations to rice and initial two irrigations } \\
\text { to wheat with canal water (supplementation of canal water } \\
\text { at sensitive stages) }\end{array}$ & 2.92 & 4.46 & 6.08 & 173.87 \\
\hline $\begin{array}{l}\mathrm{T}_{5} \text { Last two irrigations to rice but two initial and one last } \\
\text { irrigation to wheat with canal water }\end{array}$ & 2.86 & 4.36 & 5.98 & 169.36 \\
\hline
\end{tabular}

and ripening in rice crop (Kavosi, 1995; Castillo et al., 2007).

The basic principle of sustainable irrigation using brackish water is that the concentration of toxic salts in the rhizosphere must be below a specific crop threshold (Maas and Hoffman, 1977; Munns and Tester, 2008). Some reports showed that rice is tolerant to salinity at germination and sensitive during reproductive stages (Lafitte et al., 2004; Rad et al., 2011). The current study also indicated that application of canal water at the sensitive (reproductive) stages of rice and wheat growth was also more effective than consistent use of brackish water, and biomass and grain yield were significantly higher in $\mathrm{T}_{4}$ and $\mathrm{T}_{5}$ than $\mathrm{T}_{2}$. Comparatively higher values of growth attributes in $\mathrm{T}_{4}$ and $\mathrm{T}_{5}$ demonstrated that farmers can wisely manage the brackish water for irrigation when fresh water resources are limited. The sensitivity of any crop to salt stress often changes from one growth stage to the other growth stage (Mojid et al., 2014) therefore brackish water can be used for irrigation at growth stage where crops have better resistance ability (Munns and Tester, 2008). Our results are supported by previous studies that brackish water could be used for irrigation without significant crop yield loss if managed intelligently (Al Khamisi et al., 2013; Singh, 2014; Murad et al., 2018).

If properly managed, alternate irrigation with brackish and freshwater, minimize the negative impacts on plant growth and displays better soil salt control (Huang et al., 2019). Similarly, Xue and Ren (2017) reported that conjunctive use of fresh and brackish water significantly increased the yield of sunflower, maize, and wheat crop compared with brackish water irrigation. Our results are also in harmony with Minhas (1996), who stated that the conjunctive use of non-saline and saline water improved maize crop yield. Similarly, Gandahi et al. )2017) stated that cotton growth and yield attributes were significantly reduced with brackish water. The maximum values of these attributes were recorded where non-saline water was used to irrigate the crop.

\section{CONCLUSION}

Based on the current study results, it was concluded that:

Table 8: Effect of conjunctive use of brackish and canal water on soil SAR

\begin{tabular}{|c|c|c|c|c|}
\hline Treatments & $1^{\text {st }}$ year & $2^{\text {nd }}$ year & $3^{\text {rd }}$ year & $\begin{array}{l}\% \text { increase over } \\
\text { initial the value }\end{array}$ \\
\hline $\mathrm{T}_{1}$ Canal water & 5.96 & 7.50 & 7.58 & 27.39 \\
\hline $\mathrm{T}_{2}$ Consistence use of brackish water & 19.72 & 29.37 & 44.56 & 648.90 \\
\hline $\begin{array}{l}T_{3} \text { Brackish water for rice and canal water for wheat } \\
\text { seasonal cyclic use }\end{array}$ & 12.16 & 15.02 & 18.64 & 213.27 \\
\hline $\begin{array}{l}\mathrm{T}_{4} \text { Last two irrigations to rice and initial two irrigations } \\
\text { to wheat with canal water (supplementation of canal water } \\
\text { at sensitive stages) }\end{array}$ & 17.29 & 25.72 & 35.15 & 490.75 \\
\hline $\begin{array}{l}\mathrm{T}_{5} \text { Last two irrigations to rice but two initial and one last } \\
\text { irrigation to wheat with canal water }\end{array}$ & 15.82 & 22.68 & 35.14 & 490.58 \\
\hline
\end{tabular}


- Continuous use of brackish water caused the salt accumulation in soil and induced severe salt stress on crop growth and yield. Whereas, supplementation of a canal or non-saline water at sensitive growth stages can improve the rice-wheat yield significantly rather than using brackish water alone during all growth stages. Further, the cyclic mode of irrigation can be applied successfully with negligible or no negative impacts on both crop yield and soil health.
- When freshwater resources are finite and the use of brackish water is inevitable, cyclic use of brackish and canal water can ensure the reasonable and sustainable use of brackish water in agricultural production.

- Farmers in Pakistan mostly rely on tube wells that are pumping poor quality water. Alternate irrigation with brackish and canal water for major crops, like rice and wheat is an effective practice for alleviating the shortage of freshwater in agricultural production.

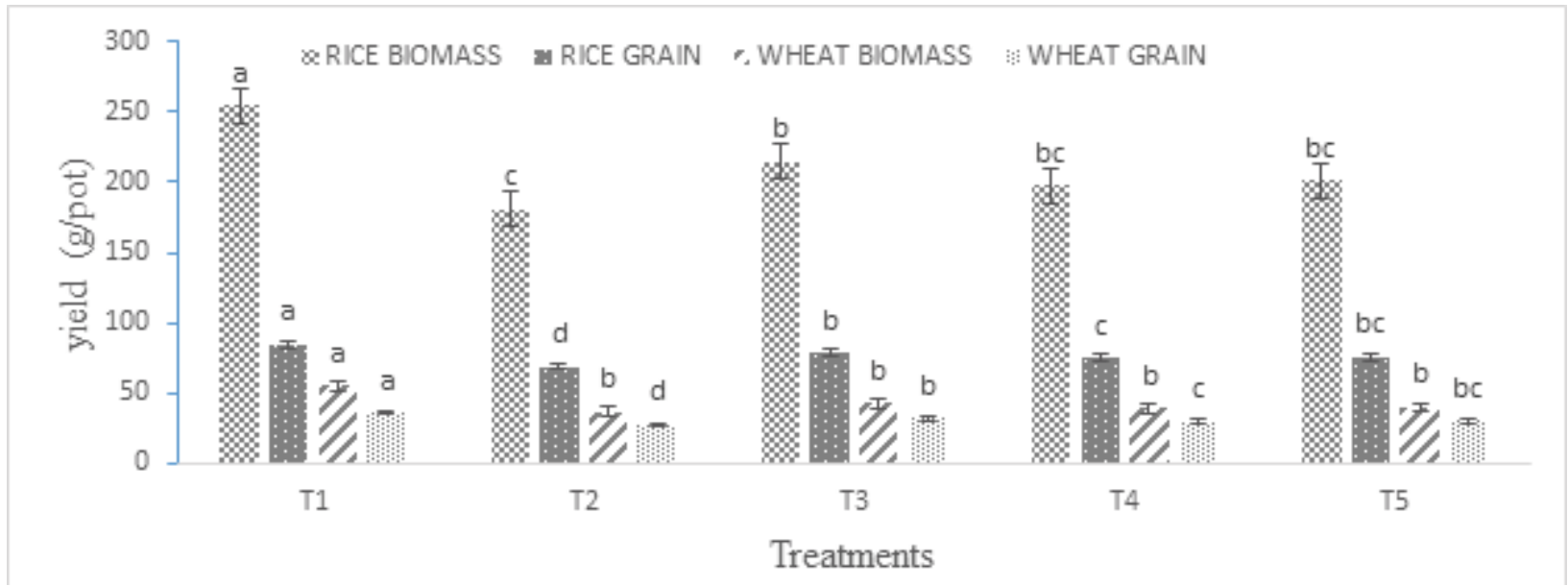

Fig.1: Effect of conjunctive use of brackish and canal water on biomass and grain yield of rice-wheat (average of three seasons). $\mathrm{T}_{1}$ (Canal water), $\mathrm{T}_{2}$ (Consistence use of brackish water), $\mathrm{T}_{3}$ (Brackish water for rice and canal water for wheat seasonal cyclic use), $\mathrm{T}_{4}$ (Last two irrigations to rice and initial two irrigations to wheat with canal water, supplementation of canal water at sensitive stages), $\mathrm{T}_{5}$ (Last two irrigations to rice but two initial and one last irrigation to wheat with canal water)

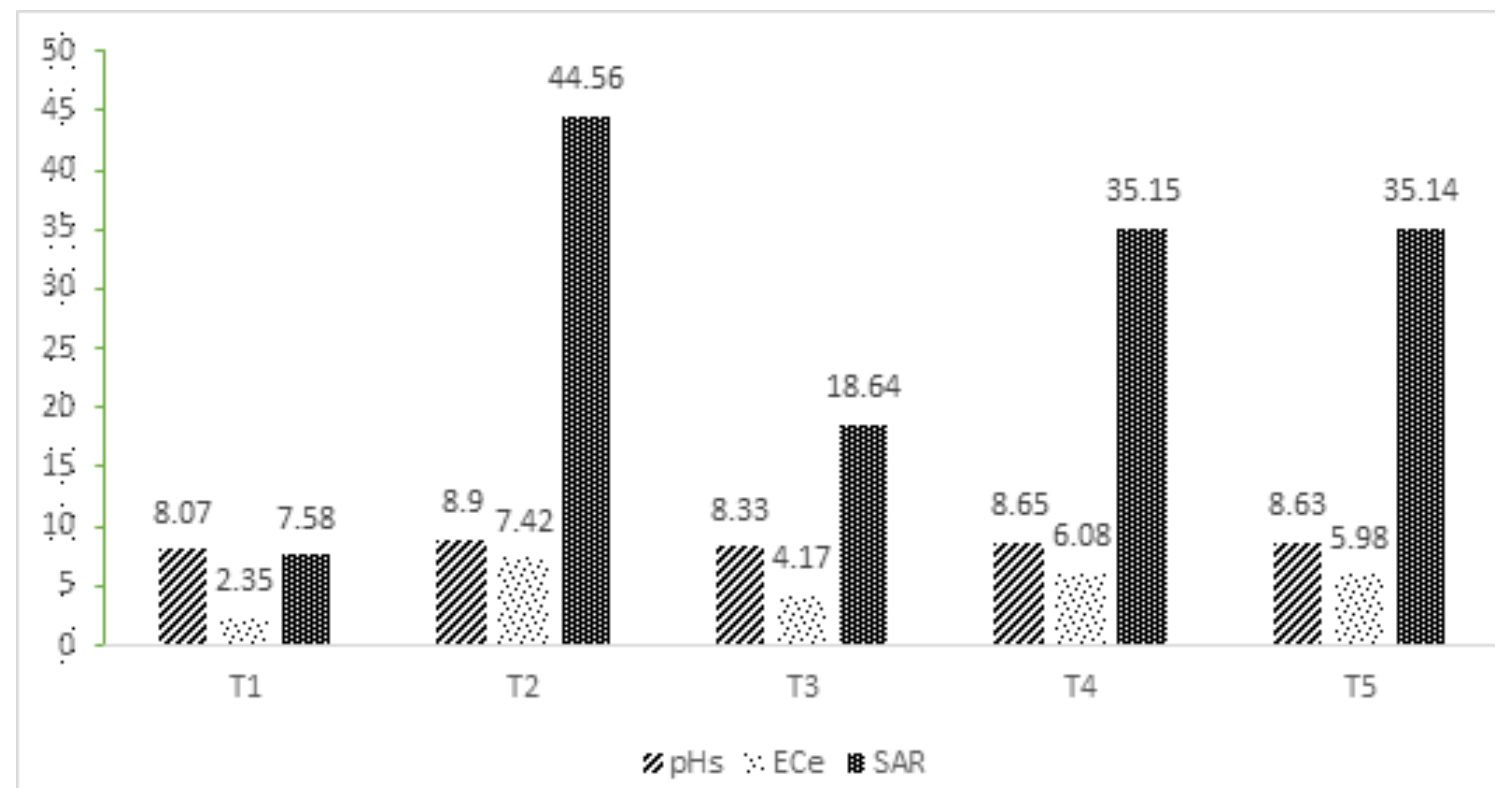

Fig.2: Effect of conjunctive use of brackish and canal water on soil $\mathrm{pH}_{s}, \mathrm{EC}_{\mathrm{e}}$ and $\mathrm{SAR}$ at the end of study. $\mathrm{T}_{1}\left(\mathrm{Canal}\right.$ water), $\mathrm{T}_{2}$ (Consistence use of brackish water), $\mathrm{T}_{3}$ (Brackish water for rice and canal water for wheat seasonal cyclic use), $\mathrm{T}_{4}$ (Last two irrigations to rice and initial two irrigations to wheat with canal water, supplementation of canal water at sensitive stages), $\mathrm{T}_{5}$ (Last two irrigations to rice but two initial and one last irrigation to wheat with canal water) 
Therefore, societal awareness among farming community to wisely use groundwater and canal water in cyclic mode for high-valued crops can potentially be helpful to avoid soil salinization and production losses.

- Current study was a pot experiment conducted in a wire house. Therefore, an additional field studies are recommended to gain a better understanding of long-term effects of brackish water and cyclic use of brackish and canal water on production of major crops and soil health.

\section{REFERENCES}

Al Khamisi, S.A., Prathapar, S.A., Ahmed, M. (2013). Conjunctive use of reclaimed water and groundwater in crop rotations. Agricultural Water Management, 116, 228-234. https://doi.org/10.1016/j.agwat.2012.07.013

Amirjani, M.R. (2011). Effect of salinity stress on growth, sugar content, pigments and enzyme activity of rice. International Journal of Botany, 7, 73-81. https://doi.org/10.3923/ ijb.2011.73.81

Avais, M.A., Ghulam, Q., Khalil, A., Muhammad, I., Amar, I.S., Imtiaz, A.W., Muhammad, Q.N., Muhammad, S., Muhammad, A. (2018). Role of inorganic and organic amendments in ameliorating the effects of brackish water for raya-sunflower production. International Journal of Biosciences, 12, 117-122.

Bedaiwy, M.N.A. (2012). A simplified approach for determining the hydrometer's dynamic settling depth in particlesize analysis. Catena, 97, 95-103. https://doi.org/10.1016/j. catena.2012.05.010

Biswas, A., Amiya, B. (2014). Comprehensive approaches in rehabilitating salt affected soils: a review on Indian perspective. Open Transactions on Geosciences, 1, 13-24. https://doi.org/10.15764/GEOS.2014.01003

Bredehoeft, J.D., Young, R. A. (1983). Conjunctive use of groundwater and surface water: Risk aversion, Water Resource Research, 19, 1111-1121. https://doi.org/10.1029/ WR019i005p01111

Castillo, E.G., To Phuc, Abdelbaghi, M.A., Kazuyuki, I. (2007). Response to salinity in rice: comparative effects of osmotic and ionic stress. Plant Production Science, 10(2), 159-170. https://doi.org/10.1626/pps.10.159

Chen, W., Menggui, J., Ty, P.A.F., Yanfeng, L., Yang, X., Tianrui, S., Xue, P. (2018). Spatial distribution of soil moisture, soil salinity, and root density beneath a cotton field under mulched drip irrigation with brackish and fresh water. Field Crops Research, 215, 207-221. https://doi. org/10.1016/j.fcr.2017.10.019

Choudhary, O.P., Ghuman, B.S., Singh, B., Thuy, N., Buresh, R.J. (2011). Effects of long-term use of sodic water irrigation, amendments and crop residues on soil properties and crop yields in rice-wheat cropping system in a calcareous soil. Field Crops Research, 121, 363-372. https://doi. org/10.1016/j.fcr.2011.01.004

De Oliveira, A.B., Alencar, N.L.M., Gomes-Filho, E. (2013).
Comparison between the water and salt stress effects on plant growth and development. In: Sener Akınc1, S. (Ed.), Responses of Organisms to Water Stress, (Publisher, Intechopen, 2013, published: January 16, 2013 under CC BY 3.0 license. 10.5772/54223). https://doi.org/10.5772/54223

Eaton, F.M. (1950). Significance of carbonate in irrigation waters. Soil Science, 67, 123-133. https://doi. org/10.1097/00010694-195002000-00004

FAO. (2011). Agriculture and water quality interactions: a global overview. SOLAW Background Thematic Report TR08. http://www.fao.org/3/bl092e/bl092e.pdf.

Gandahi, A.W., Kubar, A., Sarki, M.S., Talpur, N., Gandahi, M. (2017). Response of conjunctive use of fresh and saline water on growth and biomass of cotton genotypes. Journal of Basic \& Applied Sciences, 13, 326-334. https://doi. org/10.6000/1927-5129.2017.13.54

Ghafoor, A., Qadir, M., Qureshi, R.H. (1991). Using brackish water on normal and salt affected soil in Pakistan: A review. Pakistan Journal of Agricultural Sciences, 28, 273 288.

Huang, M., Zhang, Z., Sheng, Z., Zhu, C., Zhai, Y., Lu, P. (2019). Effect on soil properties and maize growth by alternate irrigation with brackish water. Transactions of the ASABE, 62(2), 1-9. https://doi.org/10.13031/trans.13046

Hussain, Z., Khattak, R.A., Irshad, M., Mahmood, Q., An, P. (2016). Effect of saline irrigation water on the leachability of salts, growth and chemical composition of wheat (Triticum aestivum L.) in saline-sodic soil supplemented with phosphorus and potassium. Journal of Soil Science and Plant Nutrition, 16(3), 604-620. https://doi.org/10.4067/ S0718-95162016005000031

Kavosi, M. (1995). The best model to rice yield prediction in salinity condition. Dissertation of MSc. Tabriz University.

Lafitte, H.R., Ismail, A., Bennett, J. (2004). Abiotic stress tolerance in rice Fore Asia progress and the future. International Rice Research Institute, DAPO 7777, Metro Manila, Philippines.

Latif, M., Beg, A. (2004). Hydrosalinity issues, challenges and options in OIC member states. In: M. Latif, S. Mahmood, and M.M. Saeed, eds. Proceedings of the International Training Workshop on Hydrosalinity Abatement and Advance Techniques for Sustainable Irrigated Agriculture, pp. 1-14. September 20-25, 2004. PCRWR, Islamabad.

Latteef, E.M.A. (2010). Saline irrigation water and its effect on $\mathrm{N}$ use efficiency, growth and yield of sorghum plant using 15N. MSC thesis. Al-Azhar University, Cairo. p. 46.

Levy, G.H., Mamedov, A.I., Goldstein, D. (2003). Sodicity and water quality effects on slaking of aggregates from semi-arid soils. Soil Science, 168, 552-562. https://doi. org/10.1097/01.ss.0000085050.25696.52

Maas, E.V., Hoffman, G.J. (1977). Crop salt tolerance-current assessment. Journal of the Irrigation and Drainage Division, 103, 115-134. https://doi.org/10.1061/JRCEA4.0001137

Minhas, P.S. (1996). Saline water management for irrigation in India. Agricultural Water Management, 30(1), 1-24. http://dx.doi.org/10.1016/0378-3774(95)01211-7. https:// doi.org/10.1016/0378-3774(95)01211-7

Minhas, P.S., Dubey, S.K., Sharma. D.R. (2007). Comparative 
effects of blending, intera/inter-seasonal cyclic uses of alkali and good quality waters on soil properties and yields of paddy and wheat. Agricultural Water Management, 87, 83-90. https://doi.org/10.1016/j.agwat.2006.06.003

Minhas, P.S., Gupta, R.K. (1993). Conjunctive use of saline and non-saline waters. I. Response of wheat to initially variable salinity profiles and modes of salinization. Agricultural Water Management, 23, 125-137. https://doi. org/10.1016/0378-3774(93)90036-A

Minhas, P.S., Qadir, M., Yadav, R.K. (2019). Groundwater irrigation induced soil sodification and response options. Agricultural Water Management, 215, 74-85. https://doi. org/10.1016/j.agwat.2018.12.030

Mojid, M.A., Mia, M.S., Saha, A.K., Tabriz, S.S. (2014). Growth stage sensitivity of wheat to irrigation water salinity. Journal of the Bangladesh Agricultural University, 11, 147-152. https://doi.org/10.3329/jbau.v11i1.18226

Moradi, F. (2002). Physiological characterization of rice cultivars for salinity tolerance during vegetative and reproductive stages. Ph.D Thesis. University of philippines, Los Banos. Philippines

Munns, R. (2002). Comparative physiology of salt and water stress. Plant Cell Environment, 25, 239-250. https://doi. org/10.1046/j.0016-8025.2001.00808.x

Munns, R., Tester, M. (2008). Mechanisms of salinity tolerance. Annual Review of Plant Biology, 59, 651-681.https:// doi.org/10.1146/annurev.arplant.59.032607.092911

Murad, K.F. Akbar, H., Oli, A.F., Sujit, K.B., Khokan, K.S., Rahena, P.R., Jagadish, T. (2018). Conjunctive use of saline and fresh water increases the productivity of maize in saline coastal region of Bangladesh. Agricultural Water Management, 204, 262-270. https://doi.org/10.1016/j.agwat.2018.04.019

Murtaza, B., Ghulam, M., Muhammad, S., Gary, O., Ghulam, A., Muhammad, I., Ghulam, M.S. (2017). Amelioration of saline-sodic soil with gypsum can increase yield and nitrogen use efficiency in rice-wheat cropping system. Archives of Agronomy and Soil Science, 6, 1267-1280. https://doi.org/10.1080/03650340.2016.1276285

Pessarakli, M. (2016). Handbook of Photosynthesis, third ed. CRC Press Florida, Taylor \& Francis Publishing Group p. 846. https://doi.org/10.1201/b19498

Qadir, G., Khalil, A., Amar, I.S., Muhammad, I., Muhammad, Q.N., Muhammad, S., Zaheen, M. (2019). Sustainable use of brackish water for cotton wheat rotation. Asian Journal of Agriculture and Biology, 7(4), 593-601

Qadir, M., Ghafoor, A. Murtaza, G. (2001). Use of saline sodic waters through phytoremediation of calcareous saline sodic soils. Agricultural Water Management, 50, 197-210. https://doi.org/10.1016/S0378-3774(01)00101-9

Qadir, M., Oster, J.D., Schuber S., Noble, A.D., Sahrawatk, K.L. (2007). Phytoremediation of sodic and saline-sodic soils. Advances in Agronomy, 96, 197-247. https://doi. org/10.1016/S0065-2113(07)96006-X

Qadir, M., Sharma, B.R., Bruggeman, A., Choukr-Allah, R., Karajeh, F. (2007). Non-conventional water resources and opportunities for water augmentation to achieve food security in water scarce countries. Agricultural Wa- ter Management, 87, 2-22. https://doi.org/10.1016/j.agwat.2006.03.018

Qureshi, A.S., Turral, H., Masih, I. (2004). Strategies for the management of conjunctive use of surface water and groundwater resources in semi-arid areas: A case study from Pakistan. Research Report 86. Colombo, Sri Lanka: IWMI.

Qureshi, R.H., Barrett-Lennard, E.G. (1998). Saline Agriculture for Irrigated Land in Pakistan: A handbook. Australian Centre for International Agriculture Research, Canberra.

Rad, H.E., Farshid, A., Rezaei, M., Amiri, E., Khaledian, M.R. (2011). The effects of salinity at different growth stage on rice yield. Ecology, Environment and Conservation, 17(2), 111-117.

Rhoades, J.D. (1998). Use of saline and brackish waters for irrigation: implications and role in increasing food production, conserving water, sustaining irrigation and controlling soil and water degradation. In: R. Ragab, and G. Pearce, eds. Proceedings of the International Workshop on the Use of Saline and Brackish Water for Irrigation, pp. 261-304. July 23-24, 1998, National ICID Committee, Bali, Indonesia.

Sharma, D.K., Singh, A., Sharma, P.C., Dagar, J.C., Chaudhari, S.K. (2016). Sustainable management of sodic soils for crop production: opportunities and challenges. Journal of Soil Salinity and Water Quality, 8, 109-130.

Sheoran, P., Basak, N., Ashwani Kumar, A., Yadav, R.K., Randhir, S., Raman, S., Satyendra, K., Ranjay, K., Sharma, P.C. (2021). Ameliorants and salt tolerant varieties improve rice-wheat production in soils undergoing sodification with alkali water irrigation in Indo-Gangetic Plains of India. Agricultural Water Management, 243, 1-13. https:// doi.org/10.1016/j.agwat.2020.106492

Singh, A. (2014). Conjunctive use of water resources for sustainable irrigated agriculture. Journal of Hydrology, 519, 1688-1697. https://doi.org/10.1016/j.jhydrol.2014.09.049

Steel, R.G.D., Torrie, J.H., Dickey, D.A. (1997). Principles and Procedures of Statistic: A Biometrical Approach. 3rd edition, pp, 400-428. Mc Graw Hill book Co. Inc. New York.

U.S. Salinity Lab. Staff. (1954). Diagnosis and Improvement of Saline and Alkali Soils. USDA Handbook 60, Washington DC, USA.

Xue, J., Ren, L. (2017). Conjunctive use of saline and nonsaline water in an irrigation district of the Yellow River Basin. Irrigation and Drainage, 66, 147-162. https://doi. org/10.1002/ird.2102

Zaka, M.A., Helge, S., Hafeezullah, R., Muhammad, S, Khalil, A. (2018). Utilization of brackish and canal water for reclamation and crop production. International Journal of Biosciences, 12, 7-17. https://doi.org/10.12692/ijb/12.3.717

Zeng, L., Shannon, M.C. (2003). Salinity effects on seedling growth and yield components of rice. Crop Science, 40, 996-1003. https://doi.org/10.2135/cropsci2000.404996x

Zhang, J., Lin, Y.J., Zhu, L.F., Yu, S.M., Sanjoy, K.K., Jin, Q.Y. (2015). Effects of 1-methylcyclopropene on function of flag leaf and development of superior and inferior 
spikelets in rice cultivars differing in panicle types. Field Crops Research, 177, 64-74. https://doi.org/10.1016/j. fcr.2015.03.003 